\section{EREM 74/3}

Journal of Environmental Research, Engineering and Management Vol. 74 / No. 3 / 2018 pp. 74-79

DOI 10.5755/j01.erem.74.3.20548

(c) Kaunas University of Technology
Cell-IQ Phase-contrast Microscopy for a Continuous Real-time Observation of Multipotent Mesenchymal Stromal Cell Culture
Received 2018/04
Accepted after revision 2018/05

\title{
Cell-IQ Phase-contrast Microscopy for a Continuous Real-time Observation of Multipotent Mesenchymal Stromal Cell Culture
}

\section{E.S. Melashchenko, V.V. Shupletsova, O.G. Khaziakhmatova, V.V. Malashchenko,} K.A. Yurova, L.S. Litvinova

Immanuel Kant Baltic Federal University, Laboratory of Immunology and Cell Biotechnology, Kaliningrad, 236041, Russia

\section{P.A. Golubinskaya, A.K. Zvyagina, Y.E. Burda}

LLC "Innovative Center "Biruch - New Technologies" - "EFKO" Group of Companies, R\&D Department, Alekseevka, 309850, Belgorod region, Russia

\section{L.A. Pokrovskaya}

Tomsk State University, Laboratory of Polymers and Composite Materials, Tomsk, 634050, Russia

\section{I.A. Khlusov}

Immanuel Kant Baltic Federal University, Laboratory of Immunology and Cell Biotechnology, Kaliningrad, 236041, Russia

Corresponding author: lena.melashchenko17@mail.ru

E.S.Melashchenko, Immanuel Kant Baltic Federal University, Laboratory of Immunology and Cell Biotechnology, Russia

Continuous monitoring of multipotent mesenchymal stromal cells (MMSCs) is a promising tool that could be used in cellular biology, environmental research and biotechnology to study in vitro real-time morphology and behavioural response of stem cells alone, as well at contacts with other cells and for controlling a sustainable production of scaffolds for tissue engineering. The in vitro processes of human adipose-derived MMSCs (hAMMSCs) morphology, motility, cell division, and secretion were studied by means of Cell-IQ v2 MLF (CM Technologies Oy, Finland) integrated phase-contrast microscopic platform for a continuous real-time 
surveillance imaging of living cells. $70 \mu \mathrm{L}$ suspension $\left(5 \times 10^{4}\right.$ viable karyocytes) of the cells was applied into the centre of the wells of 12-well plastic plates, and cells were allowed to adhere in a moist chamber for $120 \mathrm{~min}$. Non-adherent cells were washed, and the wells were carefully filled with $1.5 \mathrm{~mL}$ of a nutrient medium DMEM/ F12 (1: 1) without osteogenic additions. Cells were cultured for 14 days at $100 \%$ humidity in a $5 \%$ carbon dioxide atmosphere at $37^{\circ} \mathrm{C}$ until a monolayer formation. Digital images of cell culture growth were captured every $45 \mathrm{~min}$. The cells were positively stained with alizarin red (osteoblasts), alcian blue (chondrocytes), or oil red (adipocytes). More than 95\% of attached cells expressed CD73, CD90, and CD105 markers, mainly. Thus, the cells corresponded to the morphological criteria of MMSCs. The Cell-IQ system allowed establishing $182 \mu \mathrm{m} / \mathrm{h}$ linear velocity of free (until the cell contacts) motility of spindle or fibroblast-like cells. Maximum number of cells achieved 136 cells per field of view; $13-24 \%$ of cells divided each 1-3 h until a monolayer was formed. Chemokine cooperation between hAMMSCs and poor macrophages intermixture was proposed. Cell-IQ could be useful for in vitro real-time imaging of cell subpopulations and/or their response to biodegradable scaffolds and/or (micro)environmental factors.

Keywords: cell division, morphology, motility, secretion, microenvironment.

\section{Introduction}

New approaches to an investigation of adhesion, proliferation, migration, differentiation and maturation of stem cells in conditions of both two-dimensional (2D) and three-dimensional (3D) colonization of scaffolds are essential for effective tissue engineering. Various synthetic copolymers, such as PLGA (poly(lactic-co-glycolic acid) are environmentally and biologically compatible, and promising material for bone tissue engineering, but its degradation products can lower the $\mathrm{pH}$ around the implant and can induce inflammatory reactions (Kzhyshkowska et al., 2015). In turn, bone fracture triggers an inflammation that drives expansion/recruitment of endothelial, neuronal and mesenchymal stem/progenitor/precursor cells, leading to formation of a vascularized and innervated fibrous granulation tissue (Batoon et al., 2017). Bone and bone marrow contain multiple specialized resident macrophage subpopulations that contribute to bone biology and/or haematopoiesis (Kaur et al., 2017).

The interplay between macrophage inflammatory or regenerative subpopulations, stem and bone cells (Gu et al., 2017) and scaffolds is critical to physiologic and reparative bone tissue regeneration. Multipotent mesenchymal stromal cells (MMSCs) are able to migrate into inflammation and regeneration foci (Lepik et al., 2016). Thus, continuous monitoring of MMSCs is a promising tool that could be used in cellular biology, (micro)environmental research and biotechnology to study in vitro real-time morphology and behavioural response of stem cells alone, as well at contacts with other cells and for controlling a sustainable production of scaffolds for tissue engineering. However, few works have been devoted so far to modelling and determining the behaviour of MMSCs in real time (Moniri et al., 2015).

The aim of this work was to study human adipose-derived MMSCs (hAMMSCs) culture in vitro (cell morphology, motility, cell division, and secretory activity) using the Cell-IQ v2 MLF integrated phase-contrast microscopic platform for a continuous real-time surveillance imaging of living cells.

\section{Methods}

\section{MMSCs isolation}

MMSCs were isolated from lipoaspirate of 5 healthy subjects (permission no. 4 of October 23, 2013; Local Ethics Committee, Innovation Park, Immanuel Kant Baltic Federal University) as described previously (Zuk et al., 2001). To determine the stem nature of human adipose-derived MMSCs (hAMMSCs), they were cultivated in the medium with a StemPro ${ }^{\circledR}$ Differentiation Kit (Thermo Fisher Scientific, United States) for 21 days 
with medium exchange every 3-4 days. As we published previously (Litvinova et al., 2018), chondrogenic, osteogenic and adipogenic differentiations were detected by cell positive staining with alcian blue (Sigma-Aldrich, United States) and visualized proteoglycan synthesis by chondrocytes; alizarin red S (Sigma-Aldrich, United States) identified mineralization of intercellular substances in osteoblasts, and oil red (Sigma-Aldrich, United States) detected neutral triglycerides and lipids in adipocytes. This confirmed that obtained cells belonged to the pool of stem cells according to the minimal morphological criteria of the International Society for Cellular Therapy (Dominici et al., 2006).

\section{hAMMSCs behaviour}

The morphology of the attached cells and monolayer formation were monitored in vitro with a Cell-IQR v2 MLF device for continuous phase-contrast visualization of living cells in real time (CM Technologies Oy, Finland). A $70-\mu \mathrm{L}$ cell suspension $\left(5 \times 10^{4}\right.$ viable cells, fifth passage) was placed in the well centre of sterile 12-well plastic plates (Orange Scientific, Belgium). The cells were allowed to adhere for $120 \mathrm{~min}$ in a moist chamber. Unattached cells were washed out with a phosphate buffer. Then, $1.5 \mathrm{~mL}$ of the medium (90\% DMEM/ F12 (1: 1) (Gibco Life Technologies, United States), 10\% fetal bovine serum (Sigma-Aldrich, United States), $50 \mathrm{mg} / \mathrm{mL}$ gentamicin (Invitrogen, United Kingdom), and $280 \mathrm{mg} / \mathrm{mL}$ L-glutamine (Sigma-Aldrich, United States) were carefully added. The cells were cultivated in the Cell-IQ system at $37^{\circ} \mathrm{C}, 100 \%$ humidity, and $5 \% \mathrm{CO}_{2}$ for 14 days (until monolayer formation). Microscopic identification of cell morphology and cell motility is difficult in multilayer cultures.

In each well, four points were chosen for Cell-IQ phase-contrast microscopy around the initial drop of cell suspension. The points were located as follows: on the cell layer boundary (01), distantly from the cell layer and the same points on the opposite side of cell suspension. Cell culture images were captured every $45 \mathrm{~min}$, and 1308 images were obtained for each of the four points. Every tenth image was used for automatic analysis with the Cell-IQ Imagen software. Several electronic libraries of digital images were created for effective cell identification. During manual processing of videos, we determined the linear velocity of free movement of cells before they formed cell-cell contacts. The distance travelled by the cell was evaluated by the shift of the nucleus due to the variation in the shape and different sizes of migrating AMMSCs.

\section{hAMMSCs immunophenotype}

Before and after 14-day culturing, hAMMSCs cells were reattached with $0.05 \%$ trypsin (PanEco, Russia) in $0.53 \mathrm{mM}$ EDTA (Sigma-Aldrich, United States) and washed twice with phosphate buffer. The analysis of the surface markers of the viable AMMSCs was performed with human MSC Phenotyping Kit (Cat. no. 130-095-198, Miltenyi Biotec, Germany), which allowed evaluating the expression of antigenic clusters CD14, CD20,CD34, CD45, CD73, CD90, and CD105 using a MACS Quant flow cytometry (Miltenyi Biotec, Germany) according to the protocol of the manufacturer and the KALUZA Analysis Software (Beckman Coulter, United States). The concentration and viability of cells were determined with a CountessTM Automated Cell Counter (Invitrogen, United Kingdom) using $0.4 \%$ trypan blue solution (Invitrogen, United Kingdom).

\section{Cytokines and chemokines secretion in hAMMSCs culture}

Concentrations of cytokines and chemokines in the supernatants was assayed with monoclonal antibodies (Bio-Plex Pro ${ }^{\mathrm{TM}}$ Human Cytokine 21-plex Assay, Bio-Rad, United States) and the flow cytometry according to the manufacturer's instructions using automatic analyzer (Bio-Plex Protein Assay System, BioRad, United States). The concentration was expressed in $\mathrm{pg} / \mathrm{mL}$.

\section{Statistics}

The results were treated with the STATISTICA software for Windows 10.0. Testing for normality was performed using the Kolmogorov-Smirnov criterion. Median (Me), 25\% (Q1), and 75\% (Q3) quartiles were calculated. The non-parametric Mann-Whitney $U$ test was used to determine the statistical significance of differences. The differences were statistically significant at $p<0.05$. 


\section{Results and Discussion}

More than $95 \%$ of fibroblast-like or spindle adherent cells (Fig. 1) positively stained with alizarin red S (osteoblasts), alcian blue (chondrocytes), and oil red (adipocytes) expressed CD73, CD90, and CD105 markers and did not display CD45, CD34, CD20, and CD14 markers (less 5\%) (Litvinova et al., 2018). These findings showed their correspondence to the morphological criteria of MMSCs (Dominici et al., 2006; Bourin et al., 2013).

The Cell-IQ system allowed us to establish $182 \mu \mathrm{m} / \mathrm{h}$ linear velocity of free (until the cell contacts) motility of spindle or fibroblast-like human AMMSCs (Table 1). Maximum number of cells achieved 136 cells per field of view; $13-24 \%$ of cells divided each $1-3 \mathrm{~h}$ until a monolayer was obtained.

Low expression of CD14 determinant and secretion of pro-inflammatory (van den Broek et al., 2014) monokines into supernatants (Table 2) favoured to the poor macrophage intermixture of the hAMMSCs
Fig. 1

Phase-contrast Cell-IQ microscopy of unstained adipose-derived human MMSCs after 14 days of culturing. Scale bars are $200 \mu \mathrm{m}$. 0b. 40x

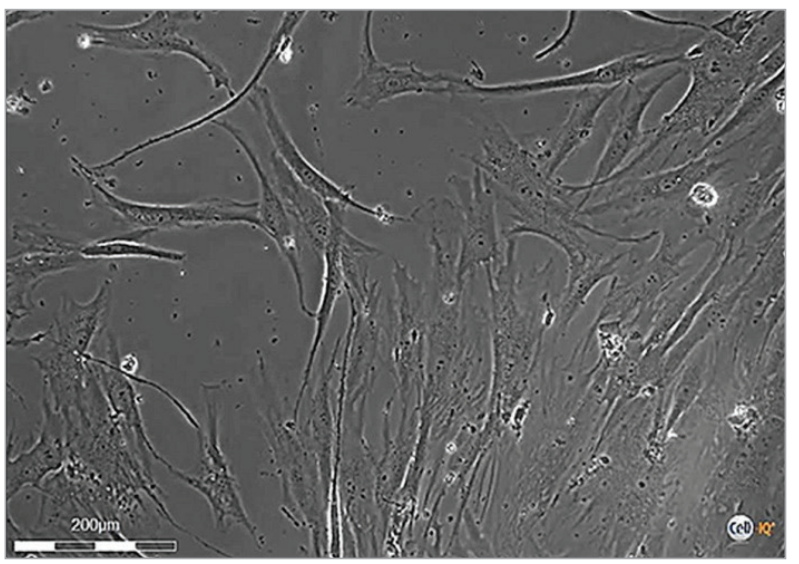

culture. In turn, chemokines influenced macrophages and expressed by them were revealed (Table 2).

Thus, humoral interplay between hAMMSCs and macrophages may control a migration and morphofunctional reactions of cell subpopulations in vitro.

\section{Table 1}

Motility and cell division of hAMMSCs before monolayer formation

\begin{tabular}{|c|c|c|c|}
\hline Manual processing of Cell-IQ video images & \multicolumn{3}{|c|}{ Software processing of Cell-IQ video images } \\
\hline 1 & \multicolumn{3}{|c|}{2} \\
\hline $\begin{array}{l}\text { Linear velocity of free motion of cells, } \\
\qquad \mu \mathrm{m} / \mathrm{h}\end{array}$ & $\begin{array}{l}\text { Number of cells per } \\
\text { visualization point }\end{array}$ & Number of cell divisions & Time of observation, $\mathrm{h}$ \\
\hline $\begin{array}{c}182(153-209) \\
n=20\end{array}$ & 93 (83-115) & $17(13-44)$ & $48(31-190)$ \\
\hline
\end{tabular}

$n=$ number of cells studied. Data are represented as median (Q1-Q3).

Table 2

Certain chemokines $(\mathrm{pg} / \mathrm{mL})$ detected in the supernatants of hAMMSCs culture in 14 days of cultivation

\begin{tabular}{c|c|c|c|c|c|c}
\hline \multicolumn{9}{c|}{ Monokines } & \multicolumn{3}{c}{ Other chemokines } \\
\hline \multicolumn{3}{c|c|}{1} & MIG (CXCL9) & SDF-1a (CXCL12) & MCP-3 (CCL7) & MIF \\
\hline M-CSF & IFNa2 & IL-12p40 & 12.8 & 53.85 & 141.21 \\
\hline 15.03 & 18.56 & 43.23 & $(33.12-66.38)$ & $(71.37-160.48)$ & $(594.29-836.08)$ \\
\hline
\end{tabular}

Data are represented as median (Q1-Q3). CCL = chemokine ( $\mathrm{C}-\mathrm{C}$ motif $)$ ligand; $\mathrm{CXCL}=$ chemokine $(\mathrm{C}-\mathrm{X}-\mathrm{C}$ motif $)$ ligand; $\mathrm{M}-\mathrm{CSF}=\mathrm{macrophage}$ colonystimulating factor; IFNa2 = interferon alpha-2; IL-12p40 = interleukin-12 subunit beta; $\mathrm{MIG}=$ monokine induced by gamma interferon; SDF-1a = stromal cellderived factor 1; MCP-3 = monocyte chemoattractant protein-3; MIF = macrophage migration inhibitory factor. $\left(^{*}\right)=$ according to van den Broek et al. (2014). 


\section{Conclusions}

The Cell-IQ phase-contrast microscopic platform allowed obtaining the multiple data of the hAMMSCs culture morphofunctional state and behaviour. It could be a useful tool for in vitro real-time imaging of an interplay between cell subpopulations and/or their morphofunctional response to biodegradable scaffolds and/or (micro)environmental factors.

\section{References}

Batoon L., Millard S.M., Raggatt L.J., Pettit A.R. (2017) Osteomacs and Bone Regeneration. Current Osteoporosis Reports 15: 385395. https://doi.org/10.1007/s11914-017-0384-X

Bourin P., Bunnell B.A., Casteilla L., Dominici M., Katz A.J., March K.L., Redl H., Rubin J.P., Yoshimura K., Gimble J.M. (2013) Stromal cells from the adipose tissue-derived stromal vascular fraction and culture expanded adipose tissue-derived stromal/ stem cells: a joint statement of the International Federation for Adipose Therapeutics and Science (IFATS) and the International Society for Cellular Therapy (ISCT). Cytotherapy 15: 641-648. https://doi.org/10.1016/j.jcyt.2013.02.006

Dominici M., Le Blanc K., Mueller I., Slaper-Cortenbach I., Marini F., Krause D., Deans R., Keating A., Prockop Dj., Horwitz E. (2006) Minimal criteria for defining multipotent mesenchymal stromal cells. The International Society for Cellular Therapy position statement. Cytotherapy 8: 315-317. https://doi. org/10.1080/14653240600855905

Gu Q., Yang H., Shi Q. (2017) Activation of macrophages in response to biomaterials. Journal of Orthopaedic Translation 10: 86-93. https://doi.org/10.1016/j.jot.2017.05.002

Kaur S, Raggatt LJ, Batoon L, Hume DA, Levesque JP, Pettit AR. (2017) Role of bone marrow macrophages in controlling homeostasis and repair in bone and bone marrow niches. Seminars in Cell \& Developmental Biology 61: 12-21. https:// doi.org/10.1016/j.semcdb.2016.08.009

Kzhyshkowska J., Gudima A., Riabov V., DollingerC., Lavalle P., Vrana N. E. (2015) Macrophage responses to implants: prospects for personalized medicine. Journal of Leukocyte Biology 98: 953962. https://doi.org/10.1189/jlb.5VMR0415-166R

Lepik K. V., Muslimov A. R., Timin A. S., Sergeev V. S., Romanyuk D. S., Moiseev I. S., Popova E. V., Radchenko I. L.,

\section{Acknowledgements}

The authors' report was presented in the "Smart Bio" conference event in Kaunas on 03-05 May 2018. The investigation was funded by the Federal Target Program of the Ministry of Education and Science of the Russian Federation (agreement 14.575.21.0164, ID number RFMEFI57517X0164).

Vilesov A. D., Galibin O. V., Sukhorukov G. B., Afanasyev B. V. (2016) Mesenchymal stem cell magnetization: magnetic multilayer microcapsule uptake, toxicity, impact onfunctional properties, and perspectives for magnetic delivery. Advanced Healthcare Materials 5: 3182-3190. https://doi.org/10.1002/ adhm.201600843

Litvinova L.S., Shupletsova V.V., Khaziakhmatova O.G., Yurova K.A., Malashchenko V.V., Melashchenko E.S. , Todosenko N.M., Khlusova M.Yu., Sharkeev Yu.P., Komarova E.G., Sedelnikova M.B., Shunkin E.O., Khlusov I.A. (2018) Behavioral Changes of Multipotent Mesenchymal Stromal Cells in Contact with Synthetic Calcium Phosphates in vitro. Cell and Tissue Biology 12(2): 112-119. https://doi.org/10.1134/S1990519X18020062

Moniri M.R., Young A., Reinheimer K., Rayat J., Dai, L-J., Warnock G.L. (2015) Dynamic assessment of cell viability, proliferation and migration using real time cell analyzer system (RTCA). Cytotechnology 67: 379-386. https://doi.org/10.1007/ s10616-014-9692-5

Zuk P.A., Zhu M., Mizuno H., Huang J., Futrell J.W., Katz A.J., Benhaim P., Lorenz H.P., Hedrick M.H. (2001) Multilineage cells from human adipose tissue: implications for cell-based therapies. Tissue Engineering 7(2): 211-228. https://doi. org/10.1089/107632701300062859

Van den Broek L.J., Kroeze K.L., Waaijman T., Breetveld M., Sampat-Sardjoepersad S.C., Niessen F.B., Middelkoop E., Scheper R.J., Gibbs S. (2014) Differential Response of Human Adipose Tissue-Derived Mesenchymal Stem Cells, Dermal Fibroblasts, and Keratinocytes to Burn Wound Exudates: Potential Role of Skin-Specific Chemokine CCL27. TISSUE ENGINEERING:Part A 20(1): 197-209. https://doi.org/10.1089/ten.tea.2013.0123 


\section{Cell-IQ fazès kontrasto mikroskopija, skirta nuolatinio daugiapoljoninès stromos ląstelių elgsenos nuolatiniam stebèjimui}

Gauta:

$2018 \mathrm{~m}$. balandis

Priimta spaudai: 2018 m. gegužè

\section{E.S. Melashchenko, V.V. Shupletsova, O.G. Khaziakhmatova, V.V. Malashchenko,}

\section{K.A. Yurova, L.S. Litvinova}

Immanuelio Kanto Baltijos federalinis universitetas, Imunologijos ir ląstelių biotechnologijos laboratorija, Kaliningradas, Rusija

\section{P.A. Golubinskaya, A.K. Zvyagina, Y.E. Burda}

LLC "Inovatyvus centras" Biruch - naujos technologijos "-" EFKO "imoniu grupè, Mokslinių tyrimų ir plètros departamentas, Rusija

\section{L.A. Pokrovskaya}

Tomskas valstybinis universitetas, Polimeru ir kompozicinių medžiagų laboratorija, Tomskas, Rusija

\section{I.A. Khlusov}

Immanuelio Kanto Baltijos federalinis universitetas, Imunologijos ir ląstelių biotechnologijos laboratorija, Kaliningradas, Tomskas valstybinis universitetas, Polimeru ir kompozicinių medžiagų laboratorija, Tomskas, Rusija

Daugelio potencialių mezenchiminių stromų ląstelių (MMSC) nuolatinè stebẻsena yra perspektyvi priemonè, kuri gali būti naudojama ląstelių biologijoje, aplinkosaugos tyrimuose ir biotechnologijose, kad būtu galima ištirti realaus laiko morfologiją ir elgesio reakciją in vitro tik kamieninių ląstelių, taip pat kontaktu su kitomis ląstelemis ir siekiant kontroliuoti tvarią pastolių gamybą audinių inžinerijos srityje. In vitro žmogaus kraujo serumo MMS serumo (hAMMSC) morfologijos, judrumo, ląstelių dalijimosi ir sekrecijos procesai buvo tiriami naudojant "Cell-IQ v2 MLF" (“CM Technologies Oy", Suomija) integruotą fazès kontrasto mikroskopinę platformą, ilgalaikio stebejjimo vaizdavimas iš gyvu ląstelių. Ląsteliu $70 \mu \mathrm{L}$ suspensija (5 × 104 gyvybingu karyocitu) buvo ipilta i 12 šulinèliu plastikiniu plokšteliu šulinèlių centrą ir ląstelėms leidžiama laikytis drègnoje kameroje $120 \mathrm{~min}$. Nekondensuojamos ląstelès buvo plaunamos, o šulinèliai buvo atsargiai pripildyti $1,5 \mathrm{ml}$ maistinès terpés DMEM / F12 (1: 1) be osteogeniniu priedų. Ląstelès buvo kultivuotos 14 dienų, esant 100\% drègmei, 5\% anglies dioksido atmosferoje $37^{\circ} \mathrm{C}$ temperatūroje, kol susidare viengubas. Skaitmeniniai ląsteliu kultūros augimo vaizdai buvo užfiksuoti kas $45 \mathrm{~min}$. Ląstelès buvo teigiamai dažytos alizarino raudonuoju (osteoblastų), alciano mèlynumo (chondrocytes) arba aliejaus raudonumo (adipocitų). Daugiau kaip $95 \%$ pririštų ląstelių daugiausia ekspresuoja CD73, CD90 ir CD105 žymenis. Taigi, ląstelès atitiko MMSC morfologinius kriterijus. "Cell-IQ" sistema leido nustatyti $182 \mu \mathrm{m} / \mathrm{h}$ linijini laisvą (iki ląstelès kontaktų) veleno arba fibroblasto tipo ląsteliu judrumą. Didžiausias ląsteliu skaičius pasiekè 136 langelius viename lauke; 13-24\% ląsteliu dalijami kas 1-3 valandas, kol susidaro monosluoksnis. Buvo pasiūlytas chemokinu bendradarbiavimas tarp aHAMMSC ir prastos makrofagu mišinys. Cell-IQ gali būti naudingas in vitro ląsteliu subpopuliaciju vaizdavimui realiuoju laiku ir / arba ju reakcijai i biologiškai skaidius pastolius ir (arba) (mikro) aplinkos veiksnius.

Raktiniai žodžiai: ląstelių susiskaidymas, morfologija, judrumas, sekrecija, mikroaplinka. 